\title{
A repressão político-judicial do Estado: a violência legítima da operação agro-fantasma e suas consequências para os agricultores campesinos da Região Sudeste do Paraná
}

\section{The political-judicial repression of the State: the legitimate violence of the operation "agrighost" and their consequences for the peasants of the Southeast Region of Paraná.}

\author{
Anne Geraldi Pimentel ${ }^{*}$ \\ Juliana de Oliveira Sales ${ }^{* \star}$ \\ Katya Regina Isaguirre -Torres ${ }^{* \star *}$ \\ Carlos Frederico Marés de Souza Filho***
}

\begin{abstract}
Resumo: Este artigo tem como objetivo analisar as prisões preventivas decretadas no curso da investigação criminal conduzida pela Polícia Federal, à suspeita de desvios de dinheiro no âmbito da execução dos projetos referentes ao Programa de Aquisição de Alimentos (PAA), que se denominou de "operação agro-fantasma". Metodologicamente a análise se vale da revisão bibliográfica; pesquisa documental, composta pelas leis, decretos e cartilhas do PAA, bem como coleta de dados empíricos por meio de entrevistas semi-estruturadas com agricultores de Irati/PR. Para isso, foram considerados os conflitos específicos do setor agrícola, no quais estão inseridos sujeitos com interesses antagônicos. Com isso, buscou-se analisar o papel do Estado, que, de forma contraditória, tem ações para a promoção do desenvolvimento social e econômico, mas também, quando necessário, utiliza-se do aparato de repressão político-judicial, com o objetivo de criminalizar os agricultores envolvidos na execução dos projetos.
\end{abstract}

Palavras-chaves: Estado. Programa de Aquisição de Alimentos (PAA). Operação agro-fantasma.

\begin{abstract}
The objective of this article is to analyze the fact of the pre-trial detention ordered in the course of the criminal investigation conducted by the Federal Police, for the suspicion of misappropriation of money on the scope of the implementation of the projects relating to Food Acquisition Program (FAP), which was denominated as "Operation agri-ghost". The methodological procedures adopted were: bibliographical review; documentary research, composed of laws, decrees and

\footnotetext{
"Formada em Direito pela UNIVEM, em Marília-SP. Mestre em Ciências Sociais e jurídicas pela UFF. Doutoranda pelo Programa de Pós Graduação em Direito da PUC-PR. Integrante do grupo de pesquisa CEPEDIS. hannah_agp@yahoo.com.br

"* Mestranda pelo Programa de Pòs-Graduação em Meio Ambiente e Desenvolvimento da UFPR-PR. juusales@gmail.com

"*t" Professora Doutora vinculada ao Programa de Pòs-Graduação em Meio Ambiente e Desenvolvimento da UFPR-PR. kisaguirre@gmail.com

**** Professor Doutor vinculado ao Programa de Pós-Graduação em Direito da PUC- PR carlosmares@terra.com.br
} 
FAP booklets, as well as empirical data collection and interviews with agricultors connected with FAP. For this analysis, it was considered the specific conflicts of the agricultural sector, who has social actors with antagonistic interests. With this, it's possible to comprise the role of the State, which, in a contradictory way, has actions to promote social and economic development, but also, when necessary, use the apparatus of political-judicial repression, with the objective of criminalizing peasants involved in the implementation of those projects.

Key-words: State. Food Acquisition Program (FAP). Operation "agri-ghost".

Recebido em: 28/07/2017. Aceito em: 08/09/2017

\section{INTRODUÇÃO}

Início da primavera, ano de 2013, o dia começa antes do sol nascer para os agricultores familiares Agricultor 1 e Agricultor $2^{1}$. E como todos os dias, a rotina era sempre a mesma: levantar, acordar a esposa e seus filhos, acender o fogão à lenha, fazer o chimarrão, preparar as crianças para pegarem o ônibus escolar municipal. A comunidade fica em área rural da cidade, não tem ônibus de linha regular e as escolas ficam nas áreas urbanas, oito ou nove quilômetros de distância. Assim, depois de tomar o café da manhã, e levar as crianças no ponto do ônibus, preparam-se para trabalhar na lavoura, ou "na roça" - como dizem lá na comunidade. Mas esse dia não foi como outro qualquer.

Às seis da manhã uma estranha movimentação muda completamente a rotina de toda a comunidade. Grandes carros pretos com listras amarelas entram em alta velocidade e fazem muito barulho, luzes giram em vermelho e azul, uma sirene anuncia a violência. Estacionam e deles descem homens vestidos de preto, com coletes de proteção peitoral, como se fossem levar tiros, carregam muitas armas, procuram pelos agricultores. E anunciam que estavam ali para executar os mandados de prisão preventiva e de busca e apreensão.

Esta cena é real, não foi ficção. Embora pareça muito com as ficções criadas por Franz Kafka (2005), autor do romance intitulado "O processo", no qual Josef K., personagem principal é abordado, inesperadamente, por policiais que

\footnotetext{
${ }^{1}$ Os agricultores assinaram o termo de autorização, no qual declaram ter conhecimento da destinação dos depoimentos para fins de pesquisa e publicação. Para a proteção dos entrevistados, seus nomes ficaram em sigilo.
}

o informam que ele cometeu um crime e será processado. Mas Josef K. não sabe que crime cometeu e irá passar toda a trama do romance clamando sua inocência. E nessa angústia, terá um trágico fim, sem saber o veredito final: culpado ou inocente.

No caso dos agricultores, a situação é um pouco diferente, sabiam que existia uma investigação criminal, instaurada no ano de 2011 pela Polícia Federal, para a investigação de suposto desvio de verbas públicas do Programa de Aquisição de Alimentos (PAA) do Governo Federal. O que não sabiam era que seriam presos, pois não imaginavam que a justiça pode ser injusta ao tratar pessoas que não oferecem risco algum com tamanha violência. Assim, este trabalho parte do pressuposto de que a deflagração de ação penal e, principalmente, a execução dos mandados de prisão preventiva foram atos de violência contra os agricultores familiares, que deixaram claro que esta violência pode mesmo ser intitulada legítima, o que, todavia, não estabelece, por si, seu caráter de violência justa.

Hannah Arendt (2009, p. 69), no texto intitulado "Sobre a violência", se propõe a análise da questão da violência no âmbito da política, com o pressuposto que violência e poder são conceitos distintos e podem, ou não, aparecerem juntos. Para Arendt (2009, p. 57), a violência tem natureza instrumental, está próxima da força, e requer "justificação pelo fim que almeja" (ARENDT, 2009, p. 68). Contudo, salienta que, embora poder e violência sejam fenômenos distintos, o domínio pela violência advém de onde o poder está em risco (ARENDT, 2009, p. 73). Importante complementar que, esta força que pode ser utilizada para a conquista ou manutenção do poder, é um dado da natureza humana, como propõe 
Maffesoli (2004, p. 83), e que é por ela, pela violência, que há um processo histórico sempre em desenvolvimento. Assim, Maffesoli (2004, p. 70) considera a violência como elemento essencial da construção simbólica do social.

Desta forma, se a violência é algo da natureza humana, na busca de determinado fim, e, como foi pressuposto, que a execução dos mandados de prisão preventiva foram atos de violência, o problema proposto neste artigo é, justamente, verificar quais são os motivos para tais atos de violência do Estado, por meio da polícia federal contra agricultores familiares. Portanto, o objetivo é analisar o fato das prisões preventivas, ao considerar as contradições específicas do setor agrícola, no qual estão inseridos sujeitos com interesses antagônicos, bem como analisar o papel do Estado nestas relações. Deve-se deixar claro e evidente que, neste artigo, a análise se limita às justificativas que a Polícia Federal deve emitir para que os mandados de prisão preventivas sejam expedidos pela Justiça Federal.

Para a construção deste artigo foram utilizados os seguintes procedimentos metodológicos: revisão bibliográfica de livros, artigos, teses que se refiram ao tema a ser investigado, aos quais foram dados os tratamentos de catalogação e referenciadas para dar suporte à construção do referencial teórico. Pesquisa documental, composta pelas leis, decretos e cartilhas do PAA, para formar a compreensão do funcionamento e objetivos destas políticas públicas. A consulta aos documentos também se valeu de acesso aos autos do processo judicial, originado pela fase de investigação conhecida como "operação agro-fantasma" e executada pela Polícia Federal no Paraná. Essa consulta processual, contudo, não se efetivou diretamente no inquérito, tendo em vista o segredo de justiça, portanto o acesso aos materiais referentes ao processo foram acessados de acordo com as peças processuais de posse dos agricultores envolvidos, dos quais se obteve autorização. Os dados empíricos foram coletados por meio de entrevistas ${ }^{2}$, orientadas

\footnotetext{
${ }^{2}$ A Polícia Federal executou 11 mandados de prisão preventiva, destes 3 foram de agricultores da associação Assis (dois da comunidade Arroio Grande, em Irati; e um do município de Inácio Martins). E para este artigo, foram entrevistado os dois agricultores da Assis que moram em Irati.
}

por um roteiro elaborado de perguntas abertas ${ }^{3}$, por entender que em uma fala livre do entrevistado é possível perceber melhor as contradições existentes no discurso.

As entrevistas foram realizadas no dia 24 de julho de 2016, uma tarde de domingo de sol e temperatura amena. Os agricultores familiares, Agricultor 1 e Agricultor 2, abriram as portas de suas casas em recepção gentil, para falar de um assunto ainda tão doloroso como uma ferida que ainda sangra, por isso, tem-se imensa gratidão. Outros momentos foram utilizados na coleta dos dados empíricos, principalmente, a fala do Agricultor 1, em um evento do projeto de extensão "Feira de Agroecologia"4, em parceria com o Núcleo Interdisciplinar de Estudos e Práticas sobre a Relação Homem Trabalho (NUHTRA), realizado no dia 12 de maio de 2016, como o tema "O trabalho familiar na agricultura camponesa agroecológica: relato dos participantes da Feira Agroecológica da UNICENTRO". Amostragem foi definida a partir do objetivo da pesquisa, que é compreender a causa da violência legitimada do Estado contra os agricultores, assim, escolheu-se, inicialmente, os responsáveis pela execução do programa nos municípios, os agricultores relacionados a Assis, ao todo foram sete indiciados na ação penal (BRASIL, 2013). Mas destes sete, foram decretada prisão preventiva de três, dos quais foram entrevistados dois.

No entanto, delimitou-se a descrição e discussão das acusações feitas aos segundo grupo, pois o foco deste artigo é compreender as razões da deflagração de ação penal e dos mandados de prisão preventiva contra os agricultores Agricultor 1 e Agricultor 2, ou seja, buscar

\footnotetext{
${ }^{3}$ Nas questões abertas, o entrevistado deverá elaborar respostas opinativas sobre a questão, o que permite ao entrevistado maior liberdade de responder da maneira como achar conveniente, cabendo ao entrevistador funções como orientação e estímulo. (RICHARDSON, 1985, p. 162)
${ }^{4} \mathrm{Na}$ Unicentro (Universidade Estadual do Centro-oeste do Pa- raná), campus de Irati/PR, existe um projeto de extensão cha- mado "Feira Agroecológica", que tem como objetivo incentivar a produção, a venda e o consumo de alimentos produzidos de forma agroecológica. Para isso, as atividades do projeto não se concentram somente na feira, realizada toda semana, mas tam- bém em atividades que buscam a formação política de todos os envolvidos no projeto (professores, alunos, funcionários, produ- tores e consumidores) através da "Roda de Mate Debate", que é realizada uma vez por mês, em espaço público, discute-se temas diversificados.
} 
A repressão político-judicial do Estado: a violência legítima da operação agro-fantasma...

entender a causa da violência legitimada do Estado contra os camponeses.

O artigo está dividido em três itens. O primeiro compreende a construção teórica sobre o Estado e suas funções no desenvolvimento social e econômico, realizada para o fim de analisar como como ocorre a intervenção estatal e qual a função que as políticas públicas de desenvolvimento possuem no cenário nacional; este item traz a discussão sobre o Estado Penal como forma de gestão da pobreza e dos indesejáveis, aplicando-se isso ao caso dos movimentos campesinos. No segundo item, em continuidade do primeiro, se fará a descrição e análise do Programa de Aquisição de Alimentos (PAA), como uma política pública do governo federal para o desenvolvimento da agricultura familiar e ao privilegiar a segurança alimentar, ou seja, como um exemplo de intervenção do Estado, através das políticas públicas, exercem sua função de desenvolvimento social e econômico. Na terceira parte se tratará da análise e descrição da "operação agro-fantasma", investigação da Polícia Federal, que culminou em processo criminal contra os agricultores familiares e outros indiciados.

Por fim, a título de contextualização, com relação à própria operação policial, é de se dizer que o inquérito teve início no ano de 2011, não se tendo informação da data precisa; os mandados de busca e apreensão e prisão preventiva, foram expedidos no dia 13 de agosto de 2013 e executados pouco mais de um mês depois, no dia 24 de setembro, antes da ação penal ser instaurada, o que ocorreu em 28 de outubro de 2013; e em 10 de dezembro de 2016, foi proferida a sentença que absolveu em primeira instância, sem recurso por parte do Ministério Público.

\section{A DICOTOMIA DO ESTADO ENTRE DESENVOLVIMENTO SOCIAL E A REPRESSÃO POLÍTICA-JUDICIAL:}

Política pública se tornou uma expressão bastante popular desde a década de 1990, sua repetição se tornou algo automático, como um sinônimo para qualquer ação do Estado e tomada sem a compreensão de seu conceito ou do contexto histórico que está inserida. Por isso, é necessária a explicitação conceitual do termo políticas públicas a partir de sua inserção no momento político, social e econômico historicamente caracterizado, para entender seu conceito e sua importância.

É importante levar em consideração que o conceito de políticas públicas está vinculado à compreensão da função do Estado como interventor da ordem social e econômica. Desde que o Estado assume, dentro do processo de desenvolvimento das forças produtivas no sistema capitalista, um caráter de Estado-nação, ele será um controlador ou interventor para a continuidade desse desenvolvimento. Mesmo que, para cumprir essa tarefa, tenha que exercer um controle sobre a escassez (GABARDO, 2009 p. 176), e implementar políticas sociais de educação, saúde, trabalho, redistribuição de renda, assistência social, entre outros. Mas os modos dessa forma de intervenção têm variado, e são alteradas de acordo com as necessidades do desenvolvimento das forças produtivas do capital, como Emerson Gabardo (2009, p. 157), ao falar sobre a ética interventora do Estado, entende que há uma "dicotomia intervenção/liberdade", provocada pelos "excessos do mercantilismo e mudança paradigmática provocada pelo renascimento e pelo desenvolvimento do capitalismo". Assim, o Estado, no processo histórico, alternou formas com maior ou menor grau de intervenção social e econômica, ora intervém de forma direta, ora indireta.

Loïc Wacquant (2001), ao analisar a dinâmica norte-americana, também percebe essa atuação oscilante do Estado. Ao pensar em uma transição do Estado Caritativo ao Estado Penal, tem-se uma dicotomia na qual a distinção reside na gestão das políticas públicas (e na gestão da miséria). Para o autor, o Estado que se chama de caritativo é caracterizado por uma maior intervenção do Estado em políticas para o desenvolvimento e de assistência social, enquanto o Estado Penal se nota na gestão da miséria com a criminalização e encarceramento dos pobres, com menor atuação na intervenção do desenvolvimento social, situação na qual os dispositivos de ajuda social seriam tidos como causas de uma "dependência patológica" dos pobres.

No Estado de Bem-estar Social, baseado nas concepções de John Maynard Keynes (HOBSBAWN, 1995, p.100), havia uma intervenção mais direta: tanto na economia, através do controle de determinados setores econômicos, nos quais a exploração era monopólio do Estado; 
quanto socialmente, neste caso, o Estado presta diretamente serviços de saúde, educação, trabalho, assistência social. Esse Estado foi constituído no pós Segunda Guerra Mundial, e que foi amplamente adotado pelos estados nacionais como modelo para o desenvolvimento das forças produtivas do capital. Bresser Pereira (1998, p.47) compreende esse modelo de Estado de Bemestar Social como de burocracia racional-legal, por demandar um Estado, com muitas funções e um aparato imenso de instituições públicas, o que requer muitos gastos públicos. O gerou, no Brasil dos anos de 1980, segundo Bresser Pereira (1998, p. 36), um colapso fiscal e, consequentemente, levou a uma crise de governabilidade. Por isso, o autor irá sugerir uma reforma deste estado burocrático.

Em meados da década de 1970, novas crises econômicas vieram a abalar o desenvolvimento das forças produtivas e, como resultado, o Estado de bem-estar social também. De acordo com Bresser Pereira (1998, p. 33) este modelo já não contribui para o desenvolvimento das forças produtivas do capital e, por isso, entra em crise mundial, fenômeno que o autor chama de "Crise do Estado". Desta forma, há autores que irão propor a liberalização da economia, como Antony Giddens (1999) e Bresser Pereira (1998), baseados no modelo de Estado Neoliberal, idealizado por Thatcher, primeira-ministra inglesa, o qual propõe a redução da intervenção do Estado na economia e no social.

Porém, volta-se a mencionar a "função essencial de controle de escassez" (GABARDO, 2009 , p. 176), pois o capitalismo para manter seu desenvolvimento, precisa da classe trabaIhadora, como o oposto e contraditório da classe burguesa, e o Estado deverá fazer concessões à classe proletária, para que ela não seja extinta. Conforme Octávio Ianni (1980), o Estado está orientado e organizado em função da acumulação do capital, mas, na sociedade de classes com interesses antagônicos, não se pode dar a uma classe sem tirar de outra, "da mesma forma que não se pode tirar tudo de uma classe, sob pena de extingui-la" (IANNI, 1980, p. 36).

Por isso, os programas sociais não devem deixar de serem implementados pelo Estado. Entretanto, após a crise econômica da década de 1970, a intervenção vai se dar através das parcerias público-privadas. Giddens (1999) será um dos precursores dessa nova forma indireta de intervenção do Estado, que irá denominar de "welfare positivo", no qual "as instituições do terceiro setor, onde não estão representadas, deveriam desempenhar um papel maior no fornecimento de serviços de welfare" (GIDDENS, 1999, p. 127).

Assim, as políticas públicas deste novo Estado liberalizado, serão realizadas, na grande maioria das vezes, através dessas parcerias público-privadas, na qual o governo entra com o recurso, que será designado à instituição privada. A escolha dessa instituição privada se dá, na administração pública, por processos de licitação, ou seja, por uma infinidade de normas, leis, editais, concorrência que caracterizam a burocracia racional-legal, tão criticada por Bresser Pereira (1998).

O PAA está inserido no âmbito desta nova racionalidade do quadro administrativo burocrático nacional, na qual o governo irá incentivar a agricultura familiar através da compra direta dos produtos, que se dará dentro das previsões legais impostas pela administração pública; e irá beneficiar as instituições de assistência social, com a doação destes alimentos. Assim, o público financia, através da compra dos alimentos produzidos pela agricultura familiar, que é privada, a alimentação saudável nas instituições de assistência social, que podem, também, ser constituídas das parcerias público-privado. Com isso, o Governo Federal cumpriu com sua função de intervenção, pois gerou desenvolvimento social através do incentivo à agricultura familiar e agroecológica, bem como, em segurança alimentar, garantiu aos usuários das redes sociassistencialistas o alimento saudável.

Contudo, como foi visto anteriormente, o Estado altera sua forma de atuação entre maior e menor intervenção. Essa transição se dá em momentos de crise econômica no modo de produção capitalista, momento em que o Estado deverá garantir a continuidade do fluxo de expansão da acumulação no capitalismo. Segundo David Harvey (2011, p. 07), o capital é um fluxo que alimenta a produção e reprodução do sistema, e que flui através do "corpo político de todas as sociedades que chamamos de capitalistas". Se esse fluxo é interrompido ou retardado, depara-se "com uma crise do capitalismo em que o cotidiano não pode mais continuar no estilo a que 
A repressão político-judicial do Estado: a violência legítima da operação agro-fantasma...

estamos acostumados". Assim, para recompor essa expansão, ou o fluxo do capital, é necessária a transição entre a intervenção e a liberalização econômica e social do Estado, mas para isso é preciso desconstruir as políticas sociais.

Loïc Wacquant (2001) fala da transformação do Estado com relação às políticas por ele implementadas, passando de uma situação caritativa ${ }^{5}$ para outra em que há a prevalência do aparato repressor - um Estado Penal, encarregado de gerenciar os pobres e a miséria. A análise deste autor se centra nas modificações sociais ocorridas nos Estados Unidos da América, que foram gradualmente expandidas ao redor do mundo e correspondem às alterações de atuação e (contra-atuação) estatal replicadas aos países latino-americanos, que, ao fim, resultam em uma "política estatal de criminalização das consequências da miséria de Estado" (WACQUANT, 2001, p. 27).

Explica-se com muita brevidade. O raciocínio de Wacquant (2001) inclui, de saída, uma diferenciação importante: de um lado a social insurance e de outro o que chama de "maldito welfare", tal distinção indica o Estado atuando de um lado para garantir os direitos dos trabalhadores tutelados estatalmente, que diz respeito à sua seguridade com relação ao desemprego, às doenças e aposentadoria e, nesse viés visto como necessário e positivo, e de outro lado, o Estado residual, cuja clientela é estigmatizada, pois seriam pessoas dependentes e miseráveis, cuja ajuda do Estado é considerada um encargo carregado por todos os cidadãos - no que se inclui uma série de políticas públicas, que carregam o estigma de assistencialistas (WACQUANT, 2001, p. 22).

Neste ponto é interessante notar como o Programa de Aquisição de Alimentos (PAA), apesar de ser indicado como uma política pública estrutural no cenário brasileiro (TAKAGI, 2010, p. 56), foi mencionado nas decisões da ação penal que tramitava perante a $13^{\mathrm{a}}$ Vara Criminal Federal da Seção de Curitiba/PR, ação relativa à operação agro-fantasma (BRASIL, 2013), como

\footnotetext{
${ }^{5} \mathrm{O}$ autor considera: "seria justo falar em Estado caritativo, na medida em que os programas voltados para a populações vulneráveis foram desde sempre limitados, fragmentários e isolados do resto das atividades estatais, informados que são por uma concepção moralista e moralizante da pobreza como produto das carências individuais dos pobres". (WACQUANT, 2001, p. 20).
}

sendo assistencialista ${ }^{6}$ - conceito que carrega em si carga pejorativa, pois reproduz ideias relacionadas à "dependência patológica" dos pobres com relação ao Estado.

Pois bem, o declínio deste Estado Caritativo se dá justamente por meio do corte de despesas governamentais e da crescente imposição de burocracia para os possíveis beneficiários das políticas públicas de assistência (do maldito welfare), faz com que a pobreza se manifeste mais claramente e demande, neste momento, outras estratégias de gestão das misérias por parte da força estatal, que vem com caráter de contenção/repressivas, o que inclui, num primeiro plano, as políticas assistenciais condicionadas, as denominadas workfare e learnfare - ou seja, benefícios somente acessados diante de condição de controle (trabalho/estudo) - e, ainda, por meio do encarceramento em massa, com destaque à sua condução pelo discurso da "guerra às drogas" (WACQUANT, 2001, p. 28-30).

O estudo de Wacquant tem como métrica o dispêndio de receita e esforços estatais para as políticas públicas voltadas aos pobres, ao considerar também a imposição de empecilhos para o acesso dos benefícios estatais. Ele revela, assim, a função latente do sistema penal, que é de gerir a miséria - ou de perpetuá-la, de colocar (ou manter a) ordem social estabelecida, além de funcionar para o armazenamento dos refugos do mercado, já que o recrutamento dos sujeitos encarcerados se dá prioritariamente junto ao subproletariado - sem esquecer os fatores de cor e raça aí implicados (2001, p. 33).

Em que pese a análise de Wacquant (2001) tenha se dado no contexto norte-americano, ela indica as consequências do sistema para a população pobre - mormente das vezes negra. Tais considerações, se consideradas de determinada perspectiva, podem auxiliar a interpretar o processo de criminalização de políticas públicas voltadas a grupos historicamente excluídos ou ainda apenas parcialmente incluídos no sistema de direitos. Isso por que o acesso às políticas do campo nem sempre são unicamente excludentes, mas podem sim conduzir formas de acesso parcial,

\footnotetext{
${ }^{6}$ Das peças as quais foi possível acessar para este trabalho, tem-se no despacho de recebimento da denúncia que "o programa tem nítido caráter assistencial. Beneficia o pequeno produtor e entidades sem fins lucrativos e de relevante caráter social" (BRASIL, 2013).
} 
o que decorre da prevalência da racionalidade econômica dominante que é substancialmente diferente das noções de trabalho e produção da agricultura camponesa, por exemplo.

A prevalência dessa racionalidade e a construção de políticas agrícolas sem aporte com a realidade do cotidiano dos agricultores é entendida aqui também como uma das múltiplas formas de violência, como se abordará ao longo desse trabalho. A análise parte dessa noção de que o Estado pode ser um agente causador de violências institucionais quando não observa as necessidades dos sujeitos do campo na criação de políticas públicas para o desenvolvimento rural.

O estudo da trajetória do Programa de Aquisição de Alimentos (PAA), sob esta perspectiva, demonstra como uma das principais estratégias de segurança alimentar no país revela a contradição perene e também histórica do Estado brasileiro na condução da política agrícola, com a criminalização da população pobre do campo, que desterradas e marginalizadas desde há muito, fora do sistema de produção do capital, têm sido massivamente alvo do poder repressivo-punitivo do Estado e de seu encarceramento (geridos de um modo mais específico e "estratégico") ${ }^{7}$, decorre daí a vulneração cada vez maior do campesinato brasileiro.

Não se pode olvidar, que no capitalismo existem relações contraditórias entre as classes proletária e a burguesa, como mencionado anteriormente, que é a contradição principal dentro do sistema. Entretanto, o desenvolvimento das forças produtivas desse modelo de produção complexifica e cria novas contradições, atreladas à principal, como ocorre com a população pobre do campo, como os campesinos, que estão em relação antagônica com os grandes proprietários de terras, os capitalistas da agricultura, o agronegócio. E esta classe, para continuar sua expansão, precisa expropriar e explorar o campesinato, e conta com o aparato estatal como instrumento

\footnotetext{
${ }^{7}$ De se rememorar outros atuais exemplos tidos em uma mesma região do estado do Paraná, nos quais as lutas sociais pela terra foram criminalizadas: o massacre ocorrido na cidade de Quedas do Iguaçu (março/2016), no qual dois integrantes de MST foram vitimados pela Polícia, tendo as próprias vítimas sido criminalizadas (pois foram presas) e a Operação Castra (novembro/2016), responsável pelo encarceramento (em caráter provisório, embora duradouro) de líderes de movimentos sociais do campo, imputando ao movimento viés de criminoso.
}

legitimador, mesmo que para isso, precise utilizar a violência. Rubens Souza e Mariana Romano (2015, p. 55), descrevem o que denominam como "repressão político-jurídica aos movimentos camponeses", num estudo que tem como objetivo a compreensão das formas judiciais criminais que reprimem esses movimentos, tanto no Brasil como na Argentina, com o intuito de garantir a continuidade da expansão do modelo hegemônico de produção agrícola.

\section{PROGRAMA DE AQUISIÇÃO DE ALIMENTOS:}

O Programa de Aquisição de Alimentos é uma política pública do governo federal que tem dois objetivos principais: promover o acesso à alimentos saudáveis e incentivar a agricultura familiar. Para isso, em modalidade específica, de compra com doação simultânea, o governo federal compra a produção dos agricultores familiares e os doa aos equipamentos da rede socioassistencial (creches, asilos, escolas) ${ }^{8}$. Por outro lado, incentiva a criação de novos espaços para a comercialização dos produtos da agricultura familiar, dos assentados da Reforma Agrária e comunidades tradicionais com o intuito de fortalecer e mantê-los no campo através de comercialização dos produtos com a administração pública.

A criação deste programa se deu no governo de Lula, no ano de 2003, instituído pelo Art. 19 da Lei $n^{\circ}$ 10.696/2003 (BRASIL, 2003a), no âmbito do Programa Fome Zero, foi regulamentado, inicialmente, pelo Decreto $n^{\circ} 4.772 / 2003$ (BRASIL, 2003b), ao qual se seguiram vários decretos e, atualmente, o decreto vigente é o de $n^{\circ} 7.775 / 2012$ (BRASIL, 2012). Essas regulamentações preveem dois tipos de beneficiários: os consumidores, que são os indivíduos em insegurança alimentar atendidos pela rede socioassistencial, aos quais os alimentos são direcionados; e os fornecedores, aqueles que produzem os alimentos e devem se enquadrar no art. $3^{\circ}$ da Lei n 11.326/2006 (BRASIL, 2006).

\footnotetext{
${ }^{8} \mathrm{O}$ artigo 17 do Decreto regulamentador $\mathrm{n}^{\circ} 7775 / 2012$ (BRASIL, 2012) descreve as seis modalidades do programa: i) compra com doação simultânea (sobre a qual incidiu a atuação da Polícia Federal aqui estudada); ii) compra direta; iii) incentivo à produção de leite e consumo; iv) apoio à formação de estoques; v) compra institucional e vi) aquisição de sementes.
} 
O programa irá, então, promover o abastecimento alimentar por meio de compras governamentais de alimentos, cujo orçamento é composto por recursos do Ministério do Desenvolvimento Social e Combate à Fome (MDS) e do Ministério do Desenvolvimento Agrário (MDA) ${ }^{9}$. A operacionalização, entre 2003 a 2012, foi feita através da Companhia Nacional de Abastecimento (CONAB), empresa pública, vinculada ao Ministério da Agricultura, Pecuária e Abastecimento (MAPA), por meio de convênios tanto para os beneficiários consumidores como para os fornecedores.

Como este artigo trata da acusação de desvio das verbas públicas pelos agricultores familiares em modalidade específica, de "Compra com Doação Simultânea”, há um recorte para comentar somente os convênios entre a CONAB e os beneficiários fornecedores no que tange à esta modalidade. Assim, desde o primeiro decreto, a compra dos produtos da agricultura familiar, executada pela CONAB, era feita através de licitação, na qual eram divulgados editais, com os requisitos para a compra. Os produtores se organizaram para concorrer a esses editais, previsto em duas modalidades: individual e coletiva. Aquele que vencia a concorrência celebrava o convênio com a CONAB para a entrega dos produtos. Hoje, com a modificação do Decreto $\mathrm{n}^{\circ} 7.775 / 2012$ (BRASIL, 2012) pelo Decreto $\mathrm{n}^{\circ}$ 8.293/2014 (BRASIL, 2014), é possível a realização da compra por chamada pública, procedimento que dispensa a licitação. Modificação que se alinha às alterações da Lei $n^{0} 12.188 / 2010$ (BRASIL, 2010), que altera o art. 24 da Lei $n^{\circ}$ 8.666/1993 (BRASIL, 1993).

Em Irati, os agricultores familiares se organizaram para formar uma associação a Assis (Associação dos Grupos de Agricultores Ecológicos São Francisco de Assis) ${ }^{10}$, que chegou

\footnotetext{
${ }^{9}$ Recorda-se que estas duas pastas ministeriais foram integradas (com a extinção do Ministério de Desenvolvimento Agrário e criação do Ministério do Desenvolvimento Social e Agrário), em razão da Medida provisória $n^{\circ} 726 / 2016$, posteriormente convertida na Lei $n^{\circ} 13.341 / 2016$ (BRASIL, 2016).

10 Para esclarecer: a Assis (Associação dos Grupos de Agricultores Ecológicos São Francisco de Assis) foi criada em 2003, com a finalidade de os agricultores poderem acessar aos programas de financiamento ou comercialização do governo nas esferas federal, estadual e municipal. Os primeiros agricultores eram da comunidade Arroio Grande, localizada na área rural de Irati; depois se expandiu para outras comunidades do município, bem como para outras cidades. Os agricultores que foram presos com a exe-
}

a ser composta por famílias de agricultores de cinco municípios da região: Irati, Inácio Martins, Fernandes Pinheiro, Teixeira Soares e Rio Azul. Ao todo, em 2013, havia 120 famílias associadas. Dessa organização, passaram a concorrer aos editais de licitação do PAA, desde de 2005 , na modalidade coletiva para a entrega dos alimentos. O Agricultor 1 fala sobre este início no evento promovido pela Unicentro, campus de Irati, no dia 12 de maio de 2016, no qual se discutiu o tema sobre o trabalho familiar na agricultura camponesa agroecológica:

\section{Agricultor 1:}

Em 2005, nós começamos a fazer parte de um programa de aquisição de alimentos, o PAA [...] Foi um projeto pequeno, de $\mathrm{R} \$ 30.000,00$, com 15 famílias, com 5 grupos de famílias, mas foi quando começou o PAA, nesse molde com alimentos agroecológico, entregando alimento para as escolas, para entidades sociais. (Feira de Agroecologia, UNICENTRO, NUHTRA, Irati, 12/5/2016).

A participação da Assis no programa aumentou expressivamente nos anos seguintes, entre 2005 e 2012, começou, como informa o agricultor Agricultor 1, com 15 famílias, e em 2013 contava com 120 famílias:

\section{Agricultor 1:}

em 2012 a associação estava com 120 famílias de agricultores e executando quase $R \$$ 1.000.000,00, entre PAA e PNAE ${ }^{11}$, com entrega de uma ou duas toneladas de alimentos toda semana, entregando para as entidades beneficiadas. (Feira de Agroecologia, UNICENTRO, NUHTRA, Irati, 12/5/2016).

É, então, notável a importância que a execução do programa teve para o fortalecimento da agricultura familiar em Irati e região. As famílias se organizaram, produziam em grande quantidade, conseguiam garantir, com isso, a renda, sustento e a produção de sua própria alimentação mais diversificada, saudável. $\mathrm{O}$ agricultor Agricultor 2 destaca a importância do PAA na saúde dele, dos familiares e da natureza:

cução do mandado de prisão preventiva eram da Assis, e foram os presidentes entre 2003 a 2013: Agricultor 1 e Agricultor 2.

${ }^{11}$ Programa Nacional de Alimentação Escolar. 
Agricultor 2 (entrevista):

A questão da saúde, não só pessoal, mas da propriedade, olhando a questão da saúde das pessoas, dos animais, do ambiente em que vive, fatores que foram complementando, toda uma melhoria de qualidade de vida dentro da propriedade.

A importância do PAA no município de Irati e região não se deveu somente à geração de renda, que possibilitou às famílias o sustento com o trabalho no campo, mas também porque tirou várias famílias do cultivo do fumo ${ }^{12}$, com a conversão para cultura agrícola de forma agroecológica. Isto porque, o programa previa um preço diferenciado para os produtos produzidos agroecológicos e orgânicos ${ }^{13}$, desde que houvesse a certificação. E na fala dos dois agricultores é perceptível que isso foi um marco na história de suas vidas, e percebem como um ganho, uma melhoria.

Agricultor 2 (entrevista):

O que eu considero o principal foi deixar de produzir matéria, para produzir alimento. Nossa propriedade produzia tabaco, e tabaco ninguém come. Começamos a produzir alimento. Isso foi uma conquista, foi um avanço. A segunda questão é a diversidade, que se produzia um tipo de cultura, na agricultura familiar diversificou-se.

Agricultor 1 (entrevista):

Meu pai plantou fumo por muito tempo e tinha ano que plantava só fumo e não dava para plantar comida. E a gente comia só batata e farinha, que era o que dava para comprar, na hora do almoço. E crescemos assim, no trabalho pesado da roça.

\footnotetext{
${ }^{12}$ A região centro-sul é grande produtora de fumo, com destaque para a cidade de Rio Azul, e seu plantio depende de muitos insumos químicos.

${ }^{13}$ Existe diferença entre produção agroecológica e orgânica, como apontam os autores Caporal e Costabeber (2015, p. 268), pois esta última embora haja a exclusão do uso de agentes químicos como os fertilizantes e agrotóxicos, ainda se baseia na monocultura, que tem impactos ao solo, levando ao cansaço e esgotamento dos seus nutrientes, além de que, esta produção também é vista como uma mercadoria, mas que possui um valor agregado, portanto, encontrada no mercado com preços elevados e inacessíveis à maioria da população. Já na produção agroecológica pretende uma produção diversificada, sem o uso de defensivos químicos, bem como a produção de alimentos com preços mais acessíveis para o consumidor.
}

A agricultura agroecológica (ALTIERI, 2012; CAPORAL e COSTABEBER, 2015; ISAGUIRRETORRES, 2012) é um sistema de produção agrícola praticado por camponeses, que valoriza o saber popular, utiliza métodos biológicos para manter a produtividade da terra e respeita a biodiversidade local. Assim, a agroecologia produz uma diversidade de alimentos, mas com respeito à natureza, ou seja, respeita à época de plantar e de colher de cada espécie de vegetal. Por exemplo, a leguminosa que é conhecida popularmente de chuchu, depende da florada do seu pé (da planta), e essa florada vai ocorrer, naturalmente, durante a primavera, portanto, é uma variedade de leguminosa de colheita na primavera e no verão. Para que haja chuchu no inverno será necessário a adequação da semente (modificação genética) e o uso de adubos e fertilizantes (agentes químicos), incompatíveis com a lógica da produção agroecológica. O agricultor familiar Agricultor 2, já na fala acima citada, menciona a produção diversificada como um benefício para si e para o meio ambiente, prossegue ao dizer:

Agricultor 2 (entrevista):

A gente conseguiu produzir, no início da proposta já, uma diversidade de 15 a 20 tipos de alimentos, isso sem custo de produção. É uma outra questão que eu gostaria de citar: os custos de produção barateou na produção de alimento.

Na produção agroecológica, como o agricultor diz acima, há menos custos de produção, isto porque, não se usa sementes transgênicas e nem os insumos (defensivos, adubos, fertilizantes) das grandes empresas químicas, que têm um alto custo ao produtor agrícola. As sementes e insumos são todos naturais, produzidos na propriedade. Assim, é possível produzir grandes quantidades e diversidade de alimentos com o sistema agroecológico, mas determinadas variedades conforme a época do alimento.

O que se constituiu um problema no PAA foi que, devido à burocracia do sistema de administração pública, não havia alterações dos produtos para contemplar as diversidades produzidas durante todo o ano. Assim, os agricultores faziam a troca das variedades, mas mantinham as quantidades e preços previstos no contrato, com a anuência da CONAB. 
Uma das característica das políticas públicas desenvolvidas por qualquer esfera de governo é a burocracia. Na análise de José Murilo de Carvalho (1997), nosso quadro administrativo burocrático no Brasil, encontra-se baseado na dominação racional-legal, está fortemente influenciado pelos fenômenos do coronelismo ${ }^{14}$, clientelismo ${ }^{15}$ e mandonismo ${ }^{16}$, formas de dominação muito características do Brasil. A questão burocrática, no sentido de administração baseada no modelo racional-legal de weberiano, também é mencionada por Arendt (2009, p. 48), mas para ela, essa é uma forma de dominação com violência, na qual é impossível a localização da responsabilidade e a identificação do inimigo, é o "domínio de ninguém".

E o PAA não foge à regra, estabelece normas, processos, leis, um sistema intrincado de departamentos são envolvidos (MDA, MDS, Conab). Um domínio da administração pública racional-legal, composto das leis, normas, exigências, que é de difícil compreensão para os agricultores. Assim, para terem acesso ao PAA, eles tinham, todos os anos, que compor um projeto de acordo com as regras do edital de chamada; prestar contas, preencher notas fiscais; fazer relatórios. Enfim, uma infinidade de burocracia. Isso era para eles uma angústia, um sofrimento, como o agricultor familiar Agricultor 1 menciona:

\footnotetext{
14 Segundo Carvalho (1997, p. 231) o conceito de coronelismo "é um sistema político nacional, baseado em barganhas entre o governo e os coronéis. O governo estadual garante, para baixo, o poder do coronel sobre seus dependentes e seus rivais, sobretudo cedendo-lhe o controle dos cargos públicos, desde o delegado de polícia até a professora primária. O coronel hipoteca seu apoio ao governo, sobretudo na forma de votos. Para cima, os governadores dão seu apoio ao Presidente da República em troca do reconhecimento deste seu domínio no estado. O coronelismo é fase de processo mais longo de relacionamento entre fazendeiros e o governo. O coronelismo não existiu antes dessa fase e não existe depois dela." O autor se refere a primeira República, entre 1889 até 1930.

${ }^{15}$ Segundo Carvalho (1997, p. 233), clientelismo "indica um tipo de relação entre atores políticos que envolve a concessão de benefícios públicos, na forma de empregos, benefícios fiscais, isenções, em troca de apoio político, sobretudo na forma de voto".

${ }^{16}$ Segundo Carvalho (1997, p. 233), o mandonismo tem o mesmo aspecto do clientelismo, mas marcado pela relação unilateral, não há aqui uma troca de favores, mas uma relação de mando, comando.
}

Agricultor 1 (entrevista):

Pode ter havido alguma falha de gestão no começo, por talvez tivesse mudado antes, um pouco antes a questão do formato de fazer as nota, né? Mas era assim, tipo, 2010, nós já estava com mais de 100 famílias e tinha variedade grande de produtos, mais de 60 variedade de produtos. E cada agricultor entregava uma porção de variedade, então, imagine você tinha que preencher duas notas por agricultor, então se for 100, 120 família tem que preencher, todo mês, quase trezentas notas, todo mês. Então para diminuir essa burocracia e não atrasar a prestação de conta fazia desse jeito. $\mathrm{E}$ aí, se não errasse, nem uma vírgula, porque se errasse um zero a nota estava cancelada [...] a gente sofreu muito por isso, ele faziam preencher aquele monte de nota, além das nota, tinha mais o termo de recebimento, tinha mais relatório, tinha um monte de coisa que tinha que fazer todo mês, um monte de papel todo mês para ir para lá. $E$ ai quando você dava um erro, qualquer coisinha que errava. la lá, daí já tinha outros projetos na frente para eles verem de volta o projeto, ia enrolando, atrasando o pagamento do projeto. E pressão dos agricultores, que o pagamento não saía.

Eram tantas as funções e exigências a serem cumpridas, que os agricultores, em cada comunidade, se organizaram para facilitar o preenchimento das notas fiscais através de um sistema de rodízio, no qual preenchiam, num mês, nota somente para um dos agricultores; no mês seguinte para outro; assim por diante. Mas para a prestação de contas de cada produtor, havia uma listagem com as quantidades e qualidades dos produtos que entregavam, e o acerto, entre eles, era realizado por uma listagem que discriminava os agricultores, o que entregavam e a quantidade, o romaneio, como dizem os agricultores:

Agricultor 1 (entrevista):

Para diminuir o número de trabalho, porque nós não tinha pessoas para trabalhar, nós diminuía as notas. Tipo aqui no grupo, por exemplo, nós tinha cinco famílias, então, no mês, isso que deu problema, nós preenchia uma nota minha, por exemplo, todas as cinco famílias entregaram, mas fechou a minha nota, $R \$ 3.500,00$ que era o meu valor total da nota, naquele mês fechava minha nota, todos os outros entregavam, daí aquilo era acertado 
com o tesoureiro. E ele sabia pelo romaneio o que cada um entregou. la para reunião e fazia o pagamento [...] daí outro mês na nota do Agricultor 2 [...].

Embora com todas essas dificuldades, de acessar e manter a execução dos projetos, o programa do Governo Federal, o PAA, conseguiu atingir suas finalidades, beneficiar os consumidores de entidades da rede socioassistencial e fortalecer a agricultura familiar. Neste caso, foi perceptível no decorrer deste item, que os agricultores familiares não só puderam suprir a renda e o sustento com o trabalho na lavoura, mas também esse trabalho trouxe a organização coletiva, muitas deixaram de plantar o fumo, converteram o plantio convencional para o agroecológico. Bem como, puderam sobreviver do trabalho na terra, com a produção de alimentos, o que hoje já não é mais possível. Isto porque, tudo começou a mudar a partir de 2012, quando a política pública do PAA passou a ser desmontada a partir de dois processos concomitantes. O primeiro que é o esvaziamento da dotação orçamentária da União, segundo dados da CONAB (2016, p.5) do ano de 2012 para 2013, o financiamento caiu, na região sul do país, de $\mathrm{R} \$ 220.557 .912,00$ (duzentos e vinte milhões quinhentos e cinquenta e sete mil e novecentos e doze reais) para $R \$ 43.203 .433,00$ (quarenta e três milhões duzentos e três mil quatrocentos e trinta e três reais), portanto um corte de $80,41 \%$ dos investimentos. E o segundo se deu com a investigação da polícia federal, iniciada em 2011, sobre os supostos desvios de recursos do programa, que ficou conhecida como "operação agro-fantasma".

\section{OPERAÇÃO AGRO-FANTASMA:}

É necessário apontar, de saída, que a "operação agro-fantasma" é interpretada neste artigo como um ato de violência, ainda que legitimada pelo sistema jurídico, pois se entende que ela é objeto material capaz de exemplificar a "hipertrofia da dimensão vigilante coercitiva-punitiva do Estado" (BRITO; ALVES; LOBO, 2012, p. 771), haja vista se concretizar, em suma, na incidência do poder punitivo sobre circunstâncias que a princípio deveriam ser tratadas como não-penais (noutras searas, como a administrativa).

Como se viu em momento anterior, os agricultores buscavam formas de facilitar a operacionalização do programa de alimentos dentro da associação, sem que houvesse vantagens ilícitas sobre tal procedimento. No entanto, a Polícia Federal passou a investigar, em 2011, as execuções dos projetos, em busca de fraudes em relação à emissão das Notas Fiscais. Como não logrou esclarecer, os supostos crimes, em cerca de dois anos de diligências, pediu à Justiça, que decretasse as medidas cautelares de prisão preventiva e busca e apreensão, mandados que foram executados em 2013, com subsequente deflagração da ação penal.

Nesta análise da operação policial, diga-se, daquilo que se considera o início da concretização do exercício punitivo estatal, tem-se como mirada o direito penal e a criminologia a partir de uma perspectiva crítica, relembrando as lições de Juarez Cirino dos Santos (2008) ao apontar a existência de um discurso oficial acerca do sistema penal, consistente em proteger os bens jurídicos, e noutro lado, a existência também de funções latentes, objetivos reais do sistema, que se relacionam à instituição e manutenção de interesses e necessidades de grupos sociais hegemônicos na formação econômico-social (2008, p. 5-6).

Essa função latente se relaciona à manutenção de um status de classe e da dominação por meio do sistema econômico do capital. Como exemplo disso, é possível citar o delito de greve previsto no Código Penal Francês de 1810, que impedia a cessão do trabalho pelo proletariado (e consequentemente proibia que se parasse com a produção de riqueza do detentor dos meios de produção, o que consiste em um preceito oculto/ latente). Situação similar que aparece no delito de vadiagem no Brasil, em 1890, logo após a abolição da escravatura, se proibindo também a greve, descrita como a "cessação ou suspensão do trabalho para impor aumento ou diminuição de serviço ou salário"17 (BRASIL, 1890, art. 206) - esses tipos penais são feitos para classes específicas e com fins específicos (embora não declarados), de manutenção da produção de riqueza. Situação que leva a concluir que pensar que o Brasil é o país da impunidade é sonegar o fato de que as classes dominantes simplesmente

\footnotetext{
17 A punição do sujeito que não tem trabalho aparece prevista também na Lei de Contravenções Penais, editada em 1941, no artigo 59.
} 
não são o alvo da punição, mas são, em realidade, imunes a ela (BATISTA, 1990, p. 35-38).

Recorda-se, em arremate, quanto a isso, a criminalização de outrora, como a havida na greve/massacre de Volta Redonda em 1988, segundo recordações de Nilo Batista (1990), na qual os trabalhadores foram considerados os delinquentes, o que não dista muito do objeto do presente estudo, visto que recentemente os criminalizados foram os trabalhadores rurais da agricultura campesina, ainda que de maneira muito mais sutil e sob o manto da legalidade.

Nada obstante, essa referência converge ao raciocínio das teorias do conflito, em sentido geral, já que elas relacionam/identificam os interesses de formação e aplicação do direito aos de grupos específicos, capazes de influenciar no processo de criminalização, indicando que esse fenômeno não é mais que uma realidade social criada por estes processos de constante criminalizar, e o próprio crime, nas palavras de Alessandro Baratta (2011, p.119), pode ser visto como "um bem negativo', distribuído desigualmente conforme a hierarquia dos interesses fixada no sistema socioeconômico e conforme a desigualdade social entre os indivíduos" (BARATTA, 2011, p. 161) .

As investigações sobre as possíveis fraudes no PAA no Estado do Paraná, como se mencionou, tiveram início em 2011, precisamente no mês de agosto, com a instauração do inquérito policial $n^{\circ}$ 0167/11, no âmbito da atribuição da Delegacia da Polícia Federal de Guarapuava, que incluía dentre os municípios a ela atribuídos, Inácio Martins - cidade na qual a associação Assis tinha atuação.

Em dezembro de 2011, as investigações se estenderam para outros municípios (Fernandes Pinheiro, Irati, Teixeira Soares e Rebouças), cuja atribuição para as investigações é da Delegacia da Polícia Federal de Curitiba, figurou, neste cenário, a associação Assis como investigada, por ser a entidade proponente do PAA nos municípios de Inácio Martins, Fernandes Pinheiro, Irati, Teixeira Soares e Rebouças.

De se notar que muito embora a atuação policial tenha ocorrido em quinze municípios paranaenses sob a mesma justificativa de deflagração (acerca de supostas irregularidades na modalidade de compra com doação simultânea do PAA), o processo-crime foi posteriormente desmembrado em oito ações penais, cujo trâmite no que atine à associação Assis foi distribuído à $13^{\text {a }}$ Vara Federal de Curitiba, vara especializada para o julgamento de delitos relacionados ao crime organizado, lavagem de dinheiro, ocultação de bens e valores, crimes contra o sistema financeiro nacional e processos do júri ${ }^{18}$.

A listagem dos crimes investigados e denunciados é extensa: associação para o crime, falsidade de documento público, falsidade ideológica, estelionato qualificado, prevaricação e peculato (os dois últimos imputados aos servidores da CONAB). Além disso, o Ministério Público, denunciou (sem provas claras) que havia a formação de uma organização criminosa, dividida em dois grupos, um desenvolvia "trabalho braçal", enquanto o outro grupo era o núcleo intelectual, interagiam para garantir o suposto desvio de recursos públicos, o que modelou a situação fática da agricultura camponesa às descrições da criminalidade organizada. Os grupos eram formados do seguinte modo, de acordo com órgão ministerial:

a) funcionários e servidores da CONAB: acusados de estelionato qualificado, pois contra entidade de direito público, art. $171, \S 3^{\circ}$ do Código Penal (BRASIL, 1940); associação criminosa, art. 288 do Código Penal (BRASIL, 1940); peculato, art. 312 do Código Penal (BRASIL, 1940); e prevaricação, art. 319 do Código Penal (BRASIL, 1940). Deste grupo foram denunciados seis pessoas, dentre eles dois ex-superintendentes regionais da CONAB, um gerente de operações e outros funcionários responsáveis pela fiscalização do programa.

b) responsáveis pela execução do programa nos municípios, os agricultores relacionados a Assis: acusados de estelionato qualificado, pois praticado contra entidade de direito público, art. $171, \S 3^{\circ}$ do Código Penal (BRASIL, 1940); associação com o fim de cometer crimes, art. 288 do Código Penal (BRASIL, 1940); falsificação de documento público, art. 297 do do Código Penal (BRASIL, 1940); e falsidade ideológica, art. 299 do Código Penal (BRASIL, 1940). Deste grupo foram denunciados sete agricultores, dentre eles, Agricultor 1 e Agricultor 2.

\footnotetext{
${ }^{18}$ Antiga $2^{\circ}$ Vara Criminal e que teve sua competência alterada uma série de vezes, por subsequentes resoluções do Tribunal

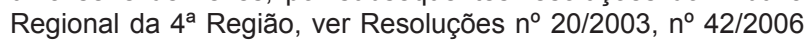
$n^{\circ} 56 / 2006, n^{\circ} 18 / 2007, n^{\circ} 99 / 2013, n^{\circ} 101 / 2014, n^{\circ}$ 96/2015 e $n^{\circ} 3 / 2016$
} 
No entanto, delimitou-se a descrição e discussão das acusações feitas aos segundo grupo, pois o foco deste artigo é compreender as razões da deflagração de ação penal e dos mandados de prisão preventiva contra os agricultores Agricultor 1 e Agricultor 2, ou seja, buscar entender a causa da violência legitimada do Estado contra os camponeses.

Importante observar, antes de tudo, na fala dos agricultores, parcialmente transcrita em outros momentos, que as irregularidades encontradas eram, de certa forma, o modo pelo qual a associação operacionalizava a burocracia do PAA, adequando-a à sua realidade, que se trata, inegável, de irregularidade administrativa, muitas vezes constatadas pela própria CONAB, embora os indícios de crime devessem, é claro, ser apurados.

A notícia que teria originado a investigação - que primeiro chegou ao conhecimento da Polícia Federal - teria sido a de que os produtos entregues pela Associação Assis às entidades beneficiadas pelo PAA não correspondiam com os valores (pesagem) e qualidades expressas no projeto aprovado na chamada pública, apontou-se que isso se daria pelo possível desvio de recursos por parte dos agricultores, o que se consubstanciou no fato imputado como estelionato qualificado.

Tais informações foram investigadas durante dois anos (desde 2011), até o que culminou na deflagração de operação policial, com o cumprimento de mandados judiciais diversos, dentre os quais os de prisão dos agricultores Agricultor 2 e Agricultor 1, que se deram já em 2013, com oferecimento de denúncia na sequência.

Foram juntados à investigação inúmeros relatórios de fiscalização/acompanhamento realizados pela CONAB acerca do programa nas cidades relacionadas à Associação Assis, muitos apontaram a realidade de necessidade de ajustes e a existência de irregularidades administrativas, sinalizaram, ainda a realização de reunião entre os agricultores e os servidores da CONAB.

A peça inaugural do processo-crime (BRASIL, 2013) se pautou na análise destas peças informativas - relatórios administrativos - e, dali retirando os indícios de crimes patrimoniais, colocou responsabilidade penal também sobre os encarregados do órgão de execução (CONAB) acerca dos supostos delitos, visto que os funcionários da CONAB foram também denunciados por prevaricação (por que, em tese, se abstiveram de seus deveres de atuação).

Assim, além de mencionar o suposto delito de estelionato contra entidade de direito público, a denúncia deu conta também do preenchimento dos termos de recebimento e aceitabilidade e dos relatórios de entrega por parte dos agricultores, imputou a eles o delito de falsidade ideológica, já que os valores ali registrados realmente não correspondiam com os valores de alimentos entregues, rememorando-se que o sistema de romaneio pressupunha a facilitação no preenchimento das notas fiscais e no registro dos alimentos entregues, sem ânimo de ludibriar a Administração Pública e tampouco fraudar a dotação orçamentária do PAA - carece, nitidamente, de elemento subjetivo - dolo - para a tipificação da conduta delitiva.

$O$ delito de associação para o crime decorreu da suposta permanência e estabilidade dos vínculos tidos entre o grupo de agricultores e os funcionários da CONAB, que, segundo a denúncia, eram mantidos com o fim de praticar condutas ilícitas, especialmente do desvio de dinheiro público - e não se voltando, assim, nenhuma menção à possibilidade de vínculos para a manutenção do programa de aquisição de alimentos.

Durante o percurso das investigações, antes mesmo do oferecimento denúncia e deflagração de processo-crime, a Polícia Federal de Curitiba formulou pedido de prisão preventiva de alguns dos investigados, no qual, frisa-se, o Ministério Público Federal se manifestou contrariamente, no sentido da adequação e suficiência de medidas cautelares diversas da prisão, como o afastamento dos envolvidos das funções ocupadas. Isto, porém, não surtiu efeito sobre a decisão judicial, que decretou as prisões preventivas ${ }^{19}$, sob argumento de que os investigados representariam risco às provas do processo, fez-se referência a possíveis intimidações de testemunhas e também que era necessário estancar a reiteração delitiva - fundamento, portanto, de "conveniência da instrução criminal" e "garantia da ordem pública”.

\footnotetext{
${ }^{19} \mathrm{O}$ juiz que assinou o mandado de prisão preventiva foi Sérgio Fernando Moro, o mesmo da "operação lava-jato".
} 
A decretação de prisão recaiu, dessa maneira, sobre os "principais componentes do grupo criminoso" e de "participação mais intensa nos crimes" (BRASIL, 2013). Dentre os presos estiveram os agricultores Agricultor 1 e Agricultor 2.

Cabe ressaltar que a prisão preventiva é medida acautelatória e excepcional, idealmente utilizada apenas nos estritos termos e requisitos da lei processual ${ }^{20}$, haja vista tratar-se do cerceamento de liberdade antes da formação de elementos bastantes da responsabilidade penal - já que utilizada durante a investigação e durante a instrução processual. Assume, por isso, caráter meramente instrumental, voltado para assegurar a realização normal do processo penal (LOPES JR., 2006, p. 212).

De toda maneira, os requisitos da decretação da prisão preventiva - da prova suficiente de autoria e materialidade delitiva e do perigo na liberdade, aliados à vagueza da letra da lei, que autoriza a prisão para "garantia da ordem pública" ${ }^{21}$ e para "garantia da ordem econômica", foi possível criar um cenário propício à inversão do processo penal acusatório.

Críticas podem ser tecidas com relação às prisões processuais, em razão de que, por vezes, se mostram incompatíveis com diretrizes básicas de um processo que se deseja acusatório, especificamente no que tange à presunção de inocência, pois diante da subjetividade dos fundamentos de decretação e do arbítrio judicial, elas podem não se prestarem, na rotina jurídica, aos fins assecuratórios que almejam - ao que se pode mencionar especificamente a justificativa vaga da "garantia da ordem pública" para a imposição de prisões questionáveis.

A decisão que decreta a preventiva, pois, deve vir suficientemente fundamentada,

\footnotetext{
${ }^{20}$ Nos termos do artigo 312 do Código de Processo Penal (BRASIL, 1941): "a prisão preventiva poderá ser decretada como garantia da ordem pública, da ordem econômica, por conveniência da instrução criminal, ou para assegurar a aplicação da lei penal, quando houver prova da existência do crime e indício suficiente de autoria". Observando-se, também, os requisitos do artigo 313 (BRASIL, 1941), que admite a prisão nos crimes dolosos com pena superior a 4 anos, nos casos de reincidência em crime doloso e na hipótese de descumprimento de medidas protetivas em casos de violência doméstica e familiar.

${ }^{21}$ A jurisprudência busca objetivar esses critérios, utilizando-se dos fatores da reincidência do acusado e da periculosidade observada em concreto para modular o conteúdo de perigo à ordem pública.
}

demonstrando juízo de probabilidade, não de possibilidade, sobre a ocorrência e a autoria do delito (LOPES, 2014, p. 570), além de trazer concretamente, por meio das provas até então coletadas, a necessidade de prisão e a insuficiência das medidas cautelares diversas desta.

No caso, Agricultor 1 e Agricultor 2 foram presos justamente com base na suposta necessidade de manter a ordem pública, e evitar a reiteração delitiva (delitos que ao final da persecução criminal se mostraram inexistentes - ainda que a retórica jurídica tenha se cingido à declaração de "não existir prova suficiente para a condenação"). Anotou-se na decretação das prisões que, por conveniência da investigação criminal, era preciso manter a normalidade da investigação e da instrução e, para isso, era preciso interromper o "ciclo de produção de documentos falsos, de intimidação de terceiros e de instigação de testemunhas a mentirem, o que exige que sejam mantidos na prisão durante a investigação e a instrução" (BRASIL, 2013).

Assim, na decretação da prisão falou-se em prática habitual e reiterada de crimes contra a Administração Pública, pois as notas fiscais seriam falsificadas deliberadamente desde 2009 , "o que impõe a preventiva para impedir a continuidade do ciclo delitivo e resgatar a confiança da sociedade no regular funcionamento das instituições públicas e na aplicação da lei penal" (BRASIL, 2013). Aqui, encontra-se um paradoxo, pois como explicar uma reiteração delitiva dentro de um mesmo processo judicial que ainda não foi julgado? Desta maneira, a Justiça passa a considerar criminoso o acusado, que segundo as garantias constitucionais, dever ser considerado inocente, até sentença judicial transitada em julgado, como previsto no inciso LVII, do art. $5^{\circ}$ da Constituição Federal (BRASIL, 1988). Não havia que se falar em ciclo delitivo e tampouco haveria substrato para falar em reiteração de delitos, já que os acusados não eram detentores de outros apontamentos criminais, mas são pessoas simples e honestas, de reputação conhecida e reconhecida por toda a comunidade, que nunca estiveram antes em uma delegacia de polícia.

As inconsistências documentais encontradas nas fiscalizações da CONAB e nas diligências policiais realizadas, não se discute, se caracterizavam indícios de crimes, tais como a falsidade documental mencionada (que pode 
ser entendida como crime-meio) e o estelionato imputados, o que, ainda assim, é incapaz de sustentar o decreto prisional cautelar, porque para isso são necessários fundamentos para a prisão, não bastando a suspeita da ocorrência do crime.

Vê-se, no entanto, que a reiteração delitiva que se pretendia evitar, com fundamento de proteger a ordem pública, nem sequer foi comprovada - não se tinha a constituição indubitável de crime anterior e que permitisse concluir que a liberdade dos investigados traria risco de reincidir na conduta - tratava-se de mera suspeita acerca da própria reiteração, uma intuição de que as condutas repetidas efetivamente eram crimes praticados desde 2009 e que deveriam ser evitados - a absolvição veio neste sentido, demonstrando não existir crime algum desde 2009. De toda forma, a argumentação fundada na suspeita da habitualidade dos crimes não subsiste, haja vista que medidas diferentes da prisão poderiam ter sido adotadas de forma satisfatória, nos termos propostos pelo Ministério Público.

Ademais, fez-se menção, quanto à conveniência da instrução criminal, ao risco que os acusados representariam às testemunhas, mencionando a "intimidação" destas por parte dos investigados. Ocorre que a decisão de decretação das prisões, transcreve uma única "ameaça", oriunda de funcionária de instituição recebedora, consistente na afirmação de que um dos agricultores teria dito que o PAA se encerraria, por corte de recursos da CONAB, se houvesse reclamações sobre os atrasos dos alimentos (BRASIL, 2013).

Para além da veracidade desta "ameaça", da qual sequer tem-se a identificação de quem a emitiu, questiona-se se ela seria suficiente para fundamentar a prisão de um número significativo de pessoas - na decisão, sob esse fundamento, foram 9 pessoas presas, por todo o estado do Paraná.

A intimidação de testemunhas e a perturbação do regular andamento das investigações é causa eficiente para a decretação da prisão, mas a verificação da dimensão e da realidade dessa interferência indevida foi ignorada, no caso.

De mais a mais, é de se destacar a mácula da prisão na vida dos dois agricultores, visto que por serem ligados a uma comunidade, assumem papel de referência, de boa índole e de trabalho, o encarceramento equiparou-se à uma condenação, ao se considerar a antecipação dos efeitos seletivos, repressivos e estigmatizantes que representa a inserção no sistema penal (BATISTA, 2007, p. 26).

Tal é a violência velada do ato de cumprimento das ordens de prisão que nos relatos dos agricultores se percebe o aparato policial desproporcional à realidade dos fatos, que os incrementa e criminaliza. Assim, no dia 24 de setembro de 2013 os mandados de prisão foram executados:

Agricultor 1 (entrevista):

Eles chegaram, perguntaram se era eu, falei que era. [...] disse para eles entrarem, mas daí já falou que eles estavam com pedido de prisão, que se eu tivesse roupa, alguma mala, que era para levar, que eles iam me levar para Curitiba [...] daí eles disseram que se fosse por bem eles não iam usar a força, eles estavam com a arma na mão, mas não me algemaram [...] perguntaram se eu queria falar, que tinha o direito de ficar calado, pelo menos até chamar advogado. Eu nem sei porque que estou preso, não vou falar nada, não tenho o que falar.

Além dos mandados de prisão contra os agricultores, simultaneamente a eles, foram expedidos mandados de busca e apreensão, a fim de constatar o enriquecimento dos investigados, pois os indícios obtidos até então davam conta apenas das irregularidades documentais, mas não atestavam a obtenção de vantagem ilícita por parte dos envolvidos, circunstância essencial para verificação do estelionato, que, em tese, era cometido desde o ano de 2009.

Por isso, os mandados se prestavam à apreensão de documentos que comprovassem os desvios de dinheiro, tais como, notas fiscais, contratos, quaisquer que demonstrassem a evolução financeira dos agricultores - documentos de veículos, matrícula de imóveis, de embarcações; documentos relativos ao pagamento de vantagens indevidas a agentes públicos e relativos à ocultação e dissimulação de pagamentos ou transferências bancárias; quantias de valores que totalizassem montante superior a $\mathrm{R} \$ 30.000,00$ (trinta mil reais) e que não tivessem comprovação de origem (BRASIL, 2013).

No entanto, nada disso foi encontrado. Conforme observou Agricultor 1 (entrevista): 
Eles vieram com a ideia de que a gente era rico, que tinha patrimônio, que tinha grandes coisas, né? Porque eles perguntavam, diz que eu tinha carro no valor de 80 mil e tinha uma embarcação, que eles queriam ver. Daí até depois quando aquele grupo dos direitos humanos que veio, até tirou foto da carroça, daí eles falaram que o carro de 80 mil era esse aqui [ele aponta para a carroça, que está no pátio]

Ideias, suposições e intuição não são provas que justifiquem o tolhimento da liberdade. Fica claro que não havia subsídio probatório para as prisões, os mandados de busca e apreensão encetados não lograram a demonstrar a materialidade dos crimes, o preenchimento das notas fiscais relacionadas ao PAA não passaram de desconhecimento, de desrespeito às formas, mas não induziram à formação ilegal de patrimônio, tanto que nada disso ficou demonstrado na fase investigatória e tampouco na instrução judicial - não se localizou provas documentais e nem testemunhas do patrimônio incompatível dos agricultores.

A reclusão de Agricultor 1 e Agricultor 2 durou quarenta e oito dias. Os danos são visíveis na fala e no choro dos trabalhadores durante as entrevistas. Eles, que durante muito tempo se dedicaram a fazer o PAA funcionar, e buscaram fortalecer a agricultura familiar e agroecológica do município de Irati e região.

$E$ após três anos de espera, a sentença foi proferida por Gabriela Hardt, como juíza substituta na $13^{a}$ Vara Federal de Curitiba, nos autos da ação penal referida (BRASIL, 2013), que declarou improcedente a denúncia do MPF e absolveu os réus, por não existir prova suficiente para a condenação, conforme o art. 386, VII do Código de Processo Penal (BRASIL, 1941). Em sede de sentença, a juíza entendeu que "não houve obtenção de vantagem ilícita atrelada às irregularidades ocorridas na execução dos PAAs nos municípios de Fernandes Pinheiro, Irati, Inácio Martins, Rebouças e Teixeira Soares" (BRASIL, 2013).

Em resumo, foi visto que o Estado, como pressuposto do desenvolvimento econômico e social, atualmente, cumpre com sua função de forma a intervir indiretamente para a construção da sociedade. Por isso, as políticas públicas assumem um papel de destaque, pois será através delas que o Estado irá agir para o desenvolvimento econômico e social. O PAA é, justamente, um desses casos, no qual a política pública tem como função a compra direta da produção agrícola de agricultores familiares, o que incentivou e fortaleceu a agricultura em pequenas propriedades em economia familiar; por outro lado, forneceu alimentos saudáveis a equipamentos de assistência social com a doação simultânea desses alimentos. Como de fato, foi verificado na localidade de Irati e cidades próximas, onde os agricultores em regime de economia familiar se reuniram e criaram uma associação, a Assis, para acessarem ao PAA.

Contudo, desde o ano de 2011, incidiu sobre o programa uma investigação por crimes de desvio de recursos públicos. $\mathrm{E}$, durante a investigação, foram expedidos mandados de prisão contra vários indiciados, dentre eles os dois agricultores entrevistados para este artigo. $\mathrm{Na}$ fundamentação, as autoridades policiais alegaram risco à ordem pública e risco para a investigação criminal, em análise com a realidade dos fatos, inferiu-se que o fundamento carecia de base e provas, portanto, as prisões foram ilegais. O que se constituiu em uma violência legitimada pelo aparato estatal repressor.

Assim, não foi encontrado justificativa legal para as prisões preventivas, mas então quer dizer que a violência foi sem finalidade? Acredita-se que não, que houve uma finalidade, pois, como Arendt (2009) coloca, a violência tem natureza instrumental, e como instrumento é orientada a um fim, que a justifica.

Percebeu-se que a violência perpetrada pela Polícia Federal na ação referente à "operação agro-fantasma” (BRASIL, 2013), foi a justificativa/causa do desmonte do PAA. Assim, a criminalização dos agricultores, com sua extensa divulgação na mídia ${ }^{22}$, criou o consenso na população que o PAA era fonte de corrupção, além de que assistencialista. Justificou, desta forma, a retração dos investimentos governamentais, que não por acaso, deu-se justamente nos anos 2012/2013.

\footnotetext{
${ }^{22}$ A mídia buscou construir uma justificativa para a violência, no imaginário popular sobre a legalidade das prisões preventivas com a utilização de recursos linguísticos, apelos sensacionalistas, descrições incorretas dos fatos, para convencer a população de que os acusados eram culpados a priori, ou seja, sem uma sentença de condenação transitada em julgado.
} 
Por outro lado, o Governo Federal, ainda com Dilma Rousseff, anunciou um aumento nos investimentos no setor agrícola que envolviam médios e grandes produtores de $8 \%$, segundo aponta Alexandro Martello e Filipe Matoso (2016b). Mas para o setor da agricultura familiar e pequenos produtores, o aumento anunciado foi de 3,67\% (MARTELLO; MATOSO, 2016a), menos da metade investido no setor de médios e grandes produtores. Além disso, já no governo provisório de Temer, o Ministério do Desenvolvimento Agrário (MDA), responsável pela execução o PAA, e transformado em Secretaria Especial de Agricultura Familiar e Desenvolvimento Agrário, vinculado à Casa Civil. Esses dados são indicativos das prioridades do governo em relação à determinada atividade, seja social ou econômica. Portanto, a extinção de um ministério que formulava e aplicava políticas públicas para o desenvolvimento da agricultura familiar, e a retração nos investimentos no setor agrícola de produtores familiares e pequenos agricultores, indicam que esta não será a prioridade do atual governo. Além disso, tem-se indícios de investimentos para a expansão do agronegócio.

\section{CONSIDERAÇÕES FINAIS}

A violência praticada pelo Estado demonstra as contradições entre classes no campo, campesinos e os grandes empresários da agricultura, o agronegócio. Isto porque a ação estatal, nas investigações de supostos crimes de fraude e corrupção, que foram nomeadas pela Polícia Federal de "operação agro-fantasma", tiveram a finalidade de desmontar as políticas públicas voltadas para o desenvolvimento econômico e social do campo, que beneficiava os sujeitos que não são totalmente incluídos no modelo da grande agricultura empresarial. A injustiça causada pela violência da ação do Estado, legitimada pelo seu poder de repressão e punição, embora sem qualquer embasamento em provas, seja por testemunhas ou por documentos, que comprovassem as alegações dos órgãos institucionais (Polícia Federal, Ministério Público e Justiça), trouxe reflexos tanto para a vida pessoal dos camponeses, quanto para a sua organização coletiva (a associação Assis).

Os efeitos da "operação agro-fantasma" foram drásticos para os campesinos. Eles não conseguem mais acessar o programa; não receberam do Estado o valor referente ao contrato executado em 2013; a associação Assis está quase extinta, restam poucas famílias associadas, mas sem qualquer perspectiva de acessarem o PAA ou outras formas de comercialização, o que enfraqueceu completamente a articulação e organização dos agricultores familiares em Irati e na região. Os agricultores entrevistados já não conseguem mais prover o sustento de sua família com a produção de sua terra, tanto que Agricultor 2 precisou sair para trabalhar como assalariado, primeiro em uma madeireira, e hoje em uma floricultura; Agricultor 1, luta com muitas dificuldades, declara que sobrevive da pensão do filho deficiente, continua a trabalhar na terra, teimosamente, voltou a plantar o fumo (orgânico, declara), e diz que não consegue deixar de trabalhar na terra.

Para além das questões sociais e econômicas dos efeitos da "operação agro-fantasma", estão as consequências morais, é perceptível na fala dos agricultores o medo, a vergonha, tristeza, sentimento de terem sofrido uma injustiça, a saudade do tempo em que estavam organizados e produziam com o trabalho coletivo. E foi com saudosismo, que no final da tarde de 24 de julho de 2016, depois de encerradas as entrevistas, Agricultor 2 e sua família fizeram questão de mostrar fotos digitais, de um antigo disco que haviam feito em 2011, em comemoração aos oito anos da Assis, em sua televisão, antiga, de tubo, com a imagem avermelhada, que está na casa há anos. Mostraram, com orgulho, as fotos, provas do tempo em que os agricultores familiares organizados, em trabalho coletivo, produziam toneladas de alimentos saudáveis.

\section{REFERÊNCIA BIBLIOGRÁFICA}

ALTIERI, M. Agroecologia: bases científicas para uma agricultura sustentável. 3ed.rev. ampl. São Paulo, Rio de Janeiro: Expressão Popular, AS-PTA, 2012.

ARENDT, Hannah. Sobre a violência. Tradução de André Duarte. Rio de Janeiro: Civilização Brasileira, 2009.

BARATTA, Alessandro. Criminologia crítica e crítica do direito penal. $6^{a}$ ed. Rio de Janeiro: Ed. Revan, Instituto Carioca de Criminologia, 2011. 
BATISTA, Nilo. Capitalismo e sistema penal: punidos e mal pagos in Punidos e mal pagos: violência, justiça, segurança pública e direitos humanos no Brasil de hoje. Rio de Janeiro: Ed. Revan, 1990.

BATISTA, Nilo. Introdução crítica ao Direito Penal Brasileiro. Rio de Janeiro: Revan, $11^{\text {a }}$ edição, 2007.

BAUDRILARD, Jean. Ensaio sobre os fenômenos extremos. Tradução de Estela dos Santos Abreu. 8ed., Campinas: Papirus, 2004.

BRASIL. 13 ${ }^{\text {a }}$ Vara Federal de Curitiba/PR. AÇÃO PENAL N ${ }^{\circ}$ 5046695-70.2013.404.7000/PR, e EPROC NN 500.2656-67.2013.404.7006, processo instaurado em 28 out. 2013.

BRASIL. Decreto-Lei $n^{\circ} 2.848$ de 07 de dezembro de 1940. Código Penal. Disponível em: <http:// www.planalto.gov.br/ccivil_03/decreto-lei/ Del2848compilado.htm>. Acesso em: 11 jul. 2017.

BRASIL. Decreto-Lei ${ }^{\circ} 3.689$ de 03 de outubro de 1941. Código de Processo Penal. Disponível em: <http://www.planalto.gov.br/ccivil_03/decreto-lei/ Del3689.htm>. Acesso em: 11 jul. 2017.

BRASIL. Constituição da República Federativa do Brasil de 1988. Disponível em: <http://www. planalto.gov.br/ccivil_03/constituicao/constituicao. htm>. Acesso em: 11 jul. 2017.

BRASIL, Lei $n^{\circ} 8.666$ de 21 de junho de 1993. Regulamenta o art. 37, inciso XXI, da Constituição Federal, institui normas para licitações e contratos da Administração Pública e dá outras providências. Disponível em <http://www.planalto.gov.br/ccivil_03/ leis/L8666cons.htm>. Acesso em: 11 jul. 2017.

BRASIL, Lei $n^{\circ} 10.696$ de 02 de junho de 2003a. Dispõe sobre a repactuação e o alongamento de dívidas oriundas de operações de crédito rural, e dá outras providências. Disponível em <http://www. planalto.gov.br/ccivil_03/leis/2003/L10.696.htm>. Acesso em: 11 jul. 2017.

BRASIL, Lei ${ }^{0} \mathbf{1 2 . 1 8 8}$ de 11 de janeiro 2010. Institui a Política Nacional de Assistência Técnica e Extensão Rural para a Agricultura Familiar e Reforma Agrária PNATER e o Programa Nacional de Assistência Técnica e Extensão Rural na Agricultura Familiar e na Reforma Agrária - PRONATER, altera a Lei n 8.666, de 21 de junho de 1993, e dá outras providências. Disponível em <http://www.planalto.gov.br/ccivil_03/_ato20072010/2010/lei/l12188.htm>. Acesso em: 11 jul. 2017.

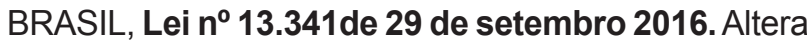
as Leis $n^{\text {os }} 10.683$, de 28 de maio de 2003 , que dispõe sobre a organização da Presidência da República e dos Ministérios, e 11.890, de 24 de dezembro de 2008, e revoga a Medida Provisória n 717, de 16 de março de 2016. Disponível em < http://www. planalto. gov.br/ccivil_03/_ato2015-2018/2016/lei/L13341.htm>. Acesso em: 11 jul. 2017.

BRASIL, Decreto $n^{\circ} \mathbf{4 . 7 7 2 d e} 02$ de julho de 2003b. Altera as Leis nos 10.683 , de 28 de maio de 2003 , que dispõe sobre a organização da Presidência da República e dos Ministérios, e 11.890, de 24 de dezembro de 2008, e revoga a Medida Provisória $\mathrm{n}^{\circ} 717$, de 16 de março de 2016. Disponível em <http:// www.planalto.gov.br/ccivil_03/decreto/2003/d4772. htm>. Acesso em: 11 jul. 2017.

BRASIL, Decreto $\mathbf{n}^{\circ} \mathbf{7 7 7 5}$ de 04 de julho de 2012 Regulamenta o art. 19 da Lei $\mathrm{n}^{\circ} 10.696$, de 2 de julho de 2003, que institui o Programa de Aquisição de Alimentos, e o Capítulo III da Lei no 12.512, de 14 de outubro de 2011, e dá outras providências. Disponível em <http://www.planalto.gov.br/ccivil_03/_ato20112014/2012/decreto/d7775.htm>. Acesso em: 11 jul. 2017.

BRITO, Felipe; ALVES, José Cláudio; LOBO, Roberta. Violência social in CALDART, Roseli Salete; PEREIRA, Isabel Brasil; ALENTEJANO, Paulo; FRIGOTTO, Gaudêncio. Dicionário de Educação do Campo. Rio de Janeiro, São Paulo: Escola Politécnica de Saúde Joaquim Venâncio, Expressão Popular, 2012.

BUCCI, Maria Paula Dallari (org.). Políticas públicas: reflexões sobre o conceito jurídico. São Paulo: Editora Saraiva, 2006.

CAPORAL, F.R.; COSTABEBER, J.A. Agroecologia: conceitos e princípios para a construção de estilos de agriculturas sustentáveis. In: NOVAES, H.(org). Questão agrária, cooperação e agroecologia. 1.ed. São Paulo: Outras Expressões, 2015, p. 263-284.

CARVALHO, José Murilo de. Mandonismo, coronelismo, clientelismo: uma discussão conceitual. DADOS Revista de Ciências Sociais. Rio de Janeiro: v. 40, $n^{\circ}$ 02, 1997.

CONAB. Programa de Aquisição de Alimentos: resultado das ações da CONAB em 2015. [online] Disponível no site: <http://www.conab.gov.br/ OlalaCMS/uploads/arquivos/16_02_02_16_00_42_ acoes_da_conab_paa_2015.pdf $>$, acesso em $0 \overline{3} \mathrm{fev}$. 2016.

GABARDO, Emerson. Interesse público e subsidiariedade: o Estado e a sociedade civil para além do bem e do mal. Belo Horizonte: Fórum, 2009. 
GIDDENS, Antony. A terceira via: reflexões sobre o impasse político atual e o futuro da social-democracia. Tradução de Maria Luiza Borges. Rio de Janeiro: Record, 1999.

HARVEY, David. E enigma do capital e as crises do capitalismo. Tradução João Alexandre Peschanski. São Paulo: Boitempo Edições, 2011.

HOBSBAWN, E. Era dos extremos: o breve século XX. São Paulo: Companhia das letras, 1995.

ISAGUIRRE-TORRES, K. R. Sistemas participativos de garantia: os sujeitos da ruralidade e seus direitos na sustentabilidade socioambiental. Tese (Doutorado) Universidade Federal do Paraná, Setor de Ciências da Terra, Programa de Pós-graduação em meio ambiente e desenvolvimento. 268 fls. UFPR: Curitiba, Paraná, 2012.

KAFKA, Franz. O processo. São Paulo: Companhia de Bolso Editora, 2005.

LOPES JR., Aury. Introdução crítica ao Processo Penal. $4^{\mathrm{a}}$ ed. Rio de Janeiro: Lumen Juris, 2006.

LOPES JR., Aury. Direito Processual Penal. $11^{\mathrm{a}}$ ed. São Paulo: Saraiva, 2014.

MAFFESOLI, Michel. A parte do diabo: resumo da subversão pós-moderna. Tradução de Clóvis Marques. Rio de Janeiro: Record, 2004.

MARTELLO, Alexandro; MATOSO, Filipe. Governo anuncia liberação de $\mathbf{R} \mathbf{3 0}$ bilhões para agricultura familiar. Globo Rural. Rio de Janeiro, 03 mai. 2016a. Disponível em: <http://g1.globo.com/economia/ agronegocios/noticia/2016/05/governo-anuncialiberacao-de-r-30-bilhoes-para-agricultura-familiar. html>, acesso em 14 jul. 2017.

MARTELLO, Alexandro; MATOSO, Filipe. Governo anuncia $\mathbf{R} \$ \mathbf{2 0 2 , 8}$ bilhões para Plano Agrícola 2016/2017. Globo Rural. Rio de Janeiro, 04 mai. 2016b. Disponível em: <http://g1.globo.com/economia/ agronegocios/noticia/2016/05/ministra-anuncia-r-2028bilhoes-para-plano-agricola-20162017.html>, acesso em 14 jul. 2017.

MARX, Karl. Sociologia. Organizador Octavio lanni; tradução Maria Elisa Mascarenhas, lone de Andrade e Fausto N. Pellegrini. São Paulo: Ática, 1980.

PEREIRA, Luiz Carlos Bresser. Reforma do Estado para a cidadania: a reforma gerencial brasileira na perspectiva internacional. São Paulo: Ed. 34, 1998.

RICHARDSON, R.J. et. al. Pesquisa social: métodos e técnicas. São Paulo: Atlas, 1985.
SANTOS, Juarez Cirino. Direito Penal: parte geral. $3^{\mathrm{a}}$ ed. Curitiba: ICPC - Lumen lures, 2008.

SOUZA, R.; ROMANO, M. Expansão do capital no campo e a repressão político-judicial dos movimentos camponeses no Brasil e na Argentina. In: TÁRREGA, M.C.V.B.; SCHWENDLER, S.F. (org.). Conflitos agrários: seus sujeitos, seus direitos. Goiânia: Ed. da PUC Goiás, 2015.

TAKAGI, Maya. A implantação do Fome Zero em 2003 in SILVA, José G. da; DEL GROSSI, Mauro E.; FRANÇA, Caio Galvão. Fome Zero: a experiência brasileira. Brasília: MDA, 2010.

WACQUANT, Loïc. Punir os pobres: a nova gestão da miséria nos Estados Unidos. Rio de Janeiro: F. Bastos, Ed. Revan, 2001. 